\title{
Comments on a Monetarist Approach to Demand Management
}

\begin{abstract}
by ROBERT H. RASCHE
Robert H. Rasche is Assistant Professor of Economics at the Wharton School of Finance and Commerce, University of Pennsylvania. He received a $\mathrm{PhD}$ degree in Economics from the University of Michigan. Professor Rasche has been closely involved in the development of the FRBMTT econometric model of the United States economy. The aththor is on leave during the 1971 . 72 academic year and is a visiting scholar at the Federal Reserve Bank of St. Lours. This paper was presented at the Annual Conference of College and University Professors of the Federal Reserve Bank of St. Louis on November 12, 1971.
\end{abstract}

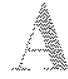

CASUAL reading of the popular discussion of stabilization policy over the past four or five years would suggest that the definition of a monetarist was firmly established. In the monetarist camp are Milton Friedman, Karl Brunner, Allan Meltzer, and the model of the St. Louis Federal Reserve Bank. Among the nonmonetarists are Walter Heller, Gardner Ackley, Arthur Okun, James Tobin, and the large econometric models such as the Wharton model and the $\mathrm{FRB}$ MIT model. Sometimes the distinction between the two groups has been summarized in the allegation that a monetarist is one who not only believes that money matters, but also believes that money is the only thing which matters. ${ }^{1}$

A close reading of the writings of those associated with both points of view, suggests that distinctions are not completely clear at the level of monetary theory. Leonall $\mathrm{C}$. Andersen has characterized the monetarist position on stabilization policy as holding that "the major impact of monetary actions is . . on longrun movements in nominal economic variables such as nominal GNP, the general price level, and market interest rates. Long-run movements in real econonic variables such as output and employment are considered to be little influenced, if at all, by monetary actions." On the other hand he admits a clear role for fiscal policy, if not the conventional stabilization policy role: "their [fiscal actions] man impact is on long-run movements of real output. . . In the short run, fiscal actions . . . exert some but litlle lasting influence on nominal GNP expansion and, therefore, have little effect on short-run movements of output and employment."

\footnotetext{
Walter W. Heller, "Us Monetary Policy Being Oversold?", in Milton Friedman and Water $v$. Heller, Monetary os. Fiscal Policy (New York: W.W. Norton \& Co, Inc, 1969), p. 16. 2 Leonall C. Andersen, "A Monetatist View of Demand Man" agement: The United States Experience" this Review /September 1971), p. 4.

Ilbid, p. 4 .
}

The question is what theoretical framework can produce these types of conclusions, and can it be tested? Again quoting the Andersen paper, "monetary actions . . . are considered a disturbance which influences the acquisition of financial and real assets. Rates of return on real and financial assets and market prices adjust to create a new equilibrium position of the economy; therefore these changes are considered the main channels of monetary infuence on aggregate demand."

Thus the monetarist conception of what has been called the transmission mechanism is one of monetary disturbances which change interest rates and the relative prices of real and financial assets. Such changes induce a reallocation of asset portfolios which can include changes in the demand for real assets. Finally, the portfolio adjustments and relative price changes can change the demand for consumables. In an earlier article in this Review, Karl Brmer characterizes a similar position as the "weak monetarist thesis."

This construct of the world is apparently one which is widely accepted among monetary economists boday and thus does not discriminate among the monetarist and nonmonetarist positions. Certainly a whole succession of writings by James Tobin suggests an explanation quite consistent with this view of the transmission mechanism of monetary policy." In fact, Andersen admits that he would view his mechanism as "close to the Tobin view, except that it takes into consideration many more rates of retum and market prices of goods and services." An examination of the

4 Tbid., p. 3 (italics are added).

"Karl Brmner, "The Role of Money and Monetary Policy" this Review (yuly 1968), pp. 18-19.

Bames Tobn, "An Essay on Principles of Debt Managenent" in Commission on Money and Credit, Fiseal and Debt Managenent Policies (Englewood Cliff, N.1.: Prentice-Hall Inc., 1963 pp. 143-218; and, "A General Equilibrium Approach to Monetary Theory," Joumal of Money, Credit and Banking (Febriary 1969) pp. 15-29.

"Andersen, "A Monetarise View," p. 3. 
writings of other nonmonetarist economists will show similar consistencies with this view of the transmission mechanism. Therefore "weak monetarism," as a theoretical position, does not appear to be a monopoly of the monetarists.

Given this apparent agreement on the theoretical basis of the mecharism through which monetary policy actions affect the economy, one can question whether the "monetarist counterrevolution" is more than an attempt at product differentiation, such as economists usually associate with monopolistic competition. A pragmatic view of the discussion suggests that at least four substantive issues are involved: (1) the usefuness of the IS-LM aggregate demand framework for policy formulation; (2) the dynamic adjustment of the economy to a new equilbrium after a policy shock; (3) the mode of conduct of monetary policy, and (4) an econometric issue of large versus small models.

\section{Limitations of Policy Prescriptions from the IS-LM Framework}

A major source of monetarist criticism has been the use of the IS-LM framework for aggregative policy analysis. In this Review, Ronald Teigen has attempted to defend the IS-LM framework from one monetarist accusation that this framework holds that an increase in the stock of money lowers the interest rate and raises output. ${ }^{8}$ He demonstrates that with certain assumptions about the relative speeds of adjustment of various markets, it is possible to show that interest rates ower time will first fall and then rise again as the system returns to a new equilibrium.

At the same time Teigen admits that this framework has ignored price expectations, and in addition, that it is not easy to incorporate price expectations, a dynamic phenomenon, into the static framework. This appears to sidestep the crux of the monetarist complaints. Not only does the conventional IS-LM analysis ignore price expectations, but it usually igneres effects from changes in the level of prices. The omission of such price level effects is possible only when the macroeconomic model is specified totally in terms of real flow variables. In sophisticated malysis, such as that of Marin Bailey, price level effects of varous kinds are introduced, and it can be shown that the position of either the IS or the LM curve (in the interest rate-real income plane) is dependent upon the current price level.

BRonald L. Teigen, "A Critical Look at Monetarist Lcononics;" this issue of the fheview, pp. 19-20.

Martin Balley, National Income and the Price Lave? (New York: MoGraw-Ell, 1962).
Most macro-economists will acknowledge the validity of the price level effect on the LM curve arising from the specification of the demand for money as a demand for real balances. Similarly, a specification of the consumption function in terms of income and wealth as implied by a permanent income or "lifecycle" hypothesis will generate a family of IS curves, one for each level of real wealth. ${ }^{10}$ Once both are constructed as functions of the price level, any policy action which generates a change in the price level will not only have a direct impact on the IS (fiscal policy) or the LM (monetary policy) curve, but also will cause additional shifts in both curves through the changes in the price level. Under these circumstances, simple multiplier calculations do not adequately represent the reaction of the economy to the policy action. Accurate policy conclusions cannot be derived without estimates of the parameters of the system.

The situation is further complicated when it is as sumed that monetary policy can affect the market value of assets, such as corporate equities, through induced changes in the rate of retum on these assets. Then the specification of a consumption-wealth relationship implies that any change in interest rates will induce a shift in the IS curve.

Teigen has already indicated that it is difficult, if not impossible, to incorporate dynamic phenomenon such as price expectations into the static framework of this construct. ${ }^{11}$ Yet, as the monetarists have rightly pointed out, adjustments in specifed behavioral relationships have to be made for such expectations under conditions of anticipated inflation (and particularly when the rate of inflation is anticipated to be changing).

It appears that the monetarists have justifiable complaints with the policy analysis derived from this framework, which is common to popular macroeconomic textbooks and past ammual reports of the Council of Economic Advisers, even if one is prepared to accept the proposition that there are no deep theoretical differences in the transmission mechanism for monetary and fiscal policy.

In many respects the monetarist attack on the IS-LM framework is fighting a "straw man." Many of the limitations of this highly aggregative framework, such as those indicated above, have been attacked in

\footnotetext{
tort is not neccessary to assume this kind of consumption function to generate swch a farmily of curves. Price elasticities of imports and exports with respect to domestic and foreign prices, or income tax functions which have nominal income elastcity greater than one, will generate the same effect.

"Tipigen; "A Critical Look," p. 19.
} 
larger econometric models of income determination. This is not to say that these models have captured the various effects with a high degree of precision. In particular, the econometric problem of estimating distribated lags has proven particularly difficult, thus the timing of responses to policy actions as implied by large statistical models is a major area of uncertainty at the present time.

\section{The Process of Adjustment to Policy Actions}

A close reading of the monetarist evaluation of the relative strengths of monetary and fiscal policy leaves the iripression that they are not quite talking about the same thing as the nonmonetarists. This can be illustrated by the first quote from Andersen, above, which sets out the transmission of monetary policy on the economy as the adjustment of rates of retum and prices to a new equilibrium (in the absence of further exogenous shocks). A similar characterization has been made in a recent analysis by Friedman in which he distinguishes "Keynesian" analysis as a framework in which prices are assumed exogenously constant. ${ }^{12}$

Most empirical models of income determination today regard the price level as endogenously determined, with the independent variables in the price level equation specified as money wage rates and productivity separately or in a composite form as unit labor costs. ${ }^{13}$ In addition, money wage rates are usually assumed to be endogenous variables in such models. The behavior of wage rates in such models is usually specified to follow a modified version of the "Phillips Curve." This specification is a disequilibrium mechanism which holds that, in the presence of an excess demand or supply in the labor market (usually measured by the unemployment rate), money wage rates will change. However, it says nothing about the nature of the equilibrium toward which the market is presumably adjusting. This is a modification of the early post-Keynestan models in which the money wage rate was taken theoretically, if not enpirically, as fixed in the short run.

\footnotetext{
12Milton Friedman, "A Theoretical Framework for Monetary Analysis," Joumal of Political Economy (March/April 1970), pp. $193-238$.

13See Lawrence R. Klein and Michael K. Evans, The Wharton Economic Forecasting Model, $2_{n}$ d ed, (Philadelphia: University of Pennsylvania, 1968); Robert Rasche and Harold T. Shapito, "The F.R.B.-M.I.T. Econometric Model: Its Special Features," American Economic Review, Papers and Proceedings (May 1968), pp. 123-149; and Otto Lickstein and Gary Fromm, "The Price Equation," American Economic Retiew (December 1968) pp. 1.159-1183.

${ }^{14}$ A. W. Phillips, "The Relationship Between Unemployment and the Rate of Change of Money Wage Rates in the United Kingdom, 1861-1957," Economica (November 1958), pp. 283-299.
}

It seems appropriate to conclude that the monetarists and their opponents are discussing policy effects on the economy over two different time spans. The nommonetarists have implicitly concerned themselves with models in which the labor market, at least, re mained in disequilibrium. The monetarists on the other hand, in discussing policy impacts when the "new equilibrium position of the cconomy" has been achieved, implicitly appear to be concerned with the period of time in which all rarkets, including the labor market, have adjusted themselves to the policy shock. The recent reinterpretation of the General Theory by Leijonhufvud offers an explanation of this debate in terms of the dynamics of the labor market. He argues:

The revolutionary impact of Keynesian Eeonomics on contemporary thought stemmed in the main, we have argued, from Keynes reversal of the conventional ranking of price and quantity velocities. In the Keynesian models price velocities are not infirite; it is sometimes said that the implications of the model result from the assumption that money wages are "rigid". This usage car be misleading. Income-constrained processes result not only when price-level velocity is zero, but whenever it is short of infuite. 15

He further argues that this is an appropriate assumption if there are substantial information costs as. sociated with trading in the labor market, as recent theories of labor market behavior have postulated: ${ }^{\text {to }}$

In the absence of perfect knowledge on the part of transacting units or of any mechanism rmrelated to the trading process itself that would supply the needed information costlesity, the presumption of infinite price velocity disappeztrs. ${ }^{1 i}$

Unfortunately, little attention has been given to empirical investigation of the process by which labor markets adjust to equilibrium. This adjustment process has significant implications for the reaction of an economic system to pure fiscal policy changes such as increased govemment expenditures on goods and services and increased real disposable income of consumers through tax reductions unaccompanied by increases in the money stock.

Acceptance of the Keynesian concepts of a consumption function and an interest elasticity of the

\footnotetext{
${ }^{15}$ Axel Leijonhufvud, On Ketnesian Economics and The Economics of Keynes (Niew York: Oxford, 1968), p. 67.

If Armen A. Alchian, "Information Costs, Pricing, and Resource Unemployment," pp. 27-52, and Charles C. Holt, "Job Search, Phillips" Wage Relations and Union Influence: Theory and Evidence" p. 53-123, both in E.S. Phelps et. al. Microcconomic Foundations of Unemployment and Inflation (New York: W.W. Norton \& Co., 1970).

17 Leijonhufvud, On Keynesian Economics, p. 69.
} 
demand for real cash balances, does not imply increases in output and employment from the above types of fiscal policy actions if the labor market is allowed to adjust to the equilibrium supply and demand functions which prevailed before the policy shock. ${ }^{18}$ The restoration of such an equilibrium implies the same real output and employment which prevailed before the policy action, that is complete "crowding ont" of the fiscal stimulus in real terms. Which elements of real private demand are displaced by the fiscal stimulus will depend on the specifications of the sector demand functions.

If the money demand function is completely interest inelastic then, when the new equilibrium is achieved, velocity must be mnchanged in the absence of an accommodating monetary expansion, and complete "crowding out" must also occur in nominal terms. With an interest elastic money demand function, higher prices can occur in the new equilibrium as a result of higher nominal interest rates. In this case complete "crowding out" will not occur in nominal terms.

The results of this model are consistent with the monetarist position on the role of fiscal policy as outlined by Andersen and others. Therefore, if the adjustment process in the labor market is relatively rapid, then the weight would seem to be with the monetarist contention that fiscal policy is a relatively weak tool for short-run stabilization. On the other hand, if the adjustment is very slow, "transitory impacts" of fiscal policy actions of the type usually derived from income determination models exist, and may have an important role in stabilization policy.

\section{The Conduct of Monetary Policy}

A consistent characteristic of the monetarist position is the insistence that monetary policy should be conducted in terms of controlling the rate of growth of monetary aggregates rather than controlling interest rates of money market conditions. This position can be traced back at least as far as early post-war proposals of Friedman during the period when the Federal Reserve was still supporting the price of Government debt. ${ }^{20}$

In support of this position, the monetarists have developed a number of valid objections to the money market approach. First, they would hold that the view

\footnotetext{
18Gardner Ackley, Macroeconomic Theory (New York: Macmillan, 1961 ), pp. 382-387.

191t is noteworthy in this respect that Friednan seems to aways be careful to acknowledge that there are shortun "transitory" effects of fiscal policy actions on real output and employment.

soMilon Friedman, A Prognam for Monetary Stability (New

York: Fordham University Press, 1959 ).
}

that monetary influences are channeled to aggregate demand only through impacts of interest rates on in vestment demand is too narrow a view of the role of monetary policy. It has been argued above that there exists fairly widespread support for this argument today, at least as a theoretical position. Second, they would argue that observed market rates of interest are nominal rates, and that in times of changing expectations of future inflation rates, the relevant interest rates for economic decisionmaking are ex ante real rates of interest - nominal rates less the anticipated rate of future inflation. Under these circumstances it is possible that changes in nominal interest rates may give a completely wrong impression of what is really happening in terms of real rates of return.

As an example of this, the St. Louis Federal Reserve Bank has published from time to time over the past several years, estimates of a real interest rate series which proposes to measure long-term yield such as the corporate bond rate adjusted for inflationary anticipations. The contrast in the behavior of this series and the corresponding nominal series is quite striking. It is well known that the nominal series has achieved historically high levels in the past several years. On the other hand, the proxy for the real rate has remained remarkably steady over the latter part of the decade. One can object, of course, to the techniques used to approximate this series. Nevertheless, the monetarists have made a valuable contribution in emphasizing this distinction, because the existence of "inflation premiums" in market interest rates, particulanly long-term rates, over the past several years is now widely acknowledged. ${ }^{21}$

An additional argument which has not been advanced by the monetarists to my knowledge, can be derived from recent work in investment theory. Considerable empirical testing has now been done or the neoclassical theory of investment which is most closely associated with the work of Jorgenson. ${ }^{22}$ This theory indicates that interest rates are but one component of the quasi rent on new capital, which is a postu-

21For example, "Financial Developments in the Third Quarter of 1971," Federal Reserve Bulletin (November 1971), p. 871 , states:

The key factor contributing to interest rate dew clines, however, was the marked change in market expectations triggered by the President's new economic program. Expectations of inflation, and hence the inflationary premitum on interest rates, appeas to have been reduced by the temporary freeze on wages and prices and by the indication that a progrann. of strong continuing controls would follow.

2xRobert E. Hall and Dale W. Jorgenson, "Application of the Theory of Optimum Capital Accumulation," pp. $9-60$, and Charles W. Bischoff, "The Effect of Alternative Lag Dis" tributions," pp. 61-130, both in Gary Fromm, ed, Tax Incentives and Capital Spending (Washington: the Brookings Institution, 1971). 
lated determinant of investment activity. Various tax policy actions can also affect the rate of return on capital, and it is the net effect of the changes in interest rates and these tax policy actions which is the relevant infuence on investment behavior. In particular, in discussions of monetary policy in late 1971, arguments that interest rates must be brought down to stimulate investment may be overly emotional. With the resumption of permanent tax credits on equipment, and the reduction of useful lives allowed for tax purposes earlier in the year through the revision of Treasury regulations, it is likely that the net effect on investment demand through the so called "cost of capital" channel would be expansionary, even if interest rates were to rise significantly over the first part of next year.

If these arguments are valid in minimizing the im portance of money market conditions as the target of monetary policy, then the question which remains to be answered is why concentrate on the rate of growth of monetary aggregates. It would seem that there is nothing in the "weak monetarist thesis," as outlined above, which is sufficient to call for the conduct of monetary policy in terms of controlling the rate of growth of monetary aggregates. The theory must be supplemented by additional hypotheses about the short-run behavior of velocity.

Brumner establishes a necessary condition for this policy orientation in what he calls the "strong mone tarist thesis," which maintains that the variability of monetary impulses is also large relative to the speed at which the economy absorbs the impact of environmental changes, 23 It does not seem totally appropriate to interpret this statement as holding that velocity is (or must be) constant in the short run, as some recent commentators seem to imply. ${ }^{24}$ All that appears necessary is that if velocity changes, it must change in a manner which is predictable from the time path of past or predicted future betavior of the money supply. It can be demonstrated with currently popular formulations of the money demand function that the lower the shortmon interest elasticity of the demand for money, the more likely this condition will be met. We shall return to this point in the next section where some comments are presented on the St. Louis equation.

Several remarks on the current state of empirical research on the money demand function are appro-

EsBrunner, "The Role of Money and Monetary Policy," p. 19. ${ }^{2}$ spanl A. Samuelson, "Reflections on the Merits and Demerits of Monetarim," in James J. Diamond, ed., Issues in Fiscal and Monetary Policy: The telectic Economist Viets The Controversy (DePaul University, 1971), pp. 7-21. priate at this point. ${ }^{25}$ It appears inappropriate to argue about the stability of the demand for money function, in the sense that the aggregate demand for real cash balances can be thought of as a stable function of a few parameters. ${ }^{20}$ This proposition has been implicitly accepted by all empirical research into the nature of this function. ${ }^{27}$ It is also true that most of these studies have concluded that statistically significant interest elasticities of money demand do exist. On the other hand the studies which have attempted to distinguish between short-run and long-run interest elasticities have consistently found that the short-rum elasticities are quite small relative to the longmrun elasticities because of a relatively slow speed of adjustment back to the longurun function after a disturbance from an initial portfolio equilibrium position.

It should be noted that these propositions say nothing about the control of the money stock through open market operations aimed at money market conditions versus control through open market operations aimed at reserve aggregate targets. This issue involves the elasticity of the supply function for money, rather than the demand function, and goes beyond the scope of the present discussion.

\section{The St. Louis Equation}

The discussion up to this point has centered on monetarism as monetary theory and its prescriptions for monetary policy. It seems appropriate to conclude with some rematks on the St. Louis equation.

This regression has been the subject of varied interpretation since it first appeared. In their original article Andersen and Jordan state:

This article does not attempt to test rival economic theories of the mechanism by which monetary and fiscal actions infuence economic activity. Neither is it intended to develop evidence bearing directly on any cansal relationships implied by such theories. More elaborate procedures than those used here would be required in order to test any theories underlying the familiar statements regarding resuls expected from monetary and fiscal actions. However, empirical relationships are developed between frequently used measures of stabilization actions and economic actixity. These relationships are consistent

$2 \mathrm{~A}$ useful summary of research on the money demand function is provided in David Laidler, The Demand for Money: Theories and Evidence (Scranton, Pa.; International Textbook Cor 1969).

26Milton Friedman, "The Quartity Theory of Money - A Restatement," in "Studies in the Quantity Theory of Money (Chicago: University of Chicago Press, 1956), pp. 3-21.

2: The derivation of regression estimates of any function presupposes stability of that function, in the Friedman sense, over the sample period. 
with the implications of some theories of stabiliza tion policy and are inconsistent with others. . . .

A later article states:

This general specification represents the reduced form for that class of structures which has $\Delta M$ [changes in money stock] and $\Delta \mathrm{E}$ [changes in Federal expenditures] as exogenous variables. In this form the total spending equation remains uncommited as to structure; it is potentially consistent with both Keynesian and quantity theory models."

In the latter article, it was also noted that equations had been constucted using percentage changes, rather than first differences, and that the restlts were basically unaffected by the change in specification.

These equations and their established forecasting properties have remained somewhat a mystery to economists associated with the nonmonetarist position and the tradition of large econometric models. It has been subjected to numerots attacks on the choice of independent variables and problems of statistical bias. ${ }^{00}$ In general it would appear that the equation has withstood these attacks surprisingly (or disturbingly) well.

We shall offer yet another interpretation of the St. Louis equation which suggests that it is not a "reduced form" of an unspecified system, but rather only one component of the structural system. This interpretation of the St. Louis results is not sympathetic to the view that the $S t$. Louis equations are a competitive econometric model of the United States economy. Judged in this perspective, it is possible to rationalize its forecasting performance.

Recognizing that percentage changes are approximately equal to changes in logarithms for small changes, the St. Lonis equation can be rewritten as:

$$
\text { (1) } \Delta \ln Y=\alpha+\sum_{i=0}^{5} \beta_{i} \Delta \ln M_{-i}+\sum_{i==0}^{5} \gamma_{i} \Delta \ln E_{-i}
$$

where $\mathrm{Y}=\mathrm{GNP}$ in current dollars

$$
\mathrm{M}=\text { money stock }
$$

$\mathrm{F}=$ high-employment Govermment expendi. tures.

\footnotetext{
2s Leonall C. Andersen and Jerry L. Jordan, "Monetary and Fiscal Actions: A Test of Their lelative Importance in Economic Stabilization," this Review (November 1968), p. 11 .

29Leonall C. Andersen and Keith M. Carlson, "A Monetarist Model for Economic Stabilization," this Review (April $1970)$, p. 9.

30 Frank de Leeuw and John Kalchbremner, "Monetary and Fiscal Actions: A Test of their Relative Importance in Economic Stabilization - Comment," this Reviet (April 1969), pp. 6-1I; and Edward M. Gramlich, "The Usefulness of Monetary and Fiscal Policy as Discretionary Stabiji. zation Tools," Joutnal of Money, Credit, and Banking (May 1971), pp. $506-532$.
}

This can in tum be conveniently transformed into a velocity ( $V$ ) equation:

(2) $\Delta \ln V=\left(\Delta \ln Y^{*}-\Delta \ln M\right)=\alpha+\left(\beta_{0}-1\right) \Delta \ln M$

$$
+\sum_{i=1}^{5} \beta_{i} \Delta \ln M_{-i}+\sum_{i=0}^{5} \gamma_{i} \Delta \ln E_{-i}
$$

Recent empirical formulations of the demand for money function specify that in the long run velocity is a function of interest rates, and assume that private economic units adjust to their long-run equilibrium cash balances with a lag. Such models can be transformed into a specification: ${ }^{31}$

(3) $\Delta \ln \mathrm{V}=\gamma_{0} \Delta \ln \mathrm{g}(\mathrm{r})+\gamma_{\mathrm{i}} \Delta \ln \mathrm{M}_{\mathrm{t}}+\sum_{\mathrm{i}=1}^{\mathrm{n}} \gamma_{\mathrm{i}} \Delta \ln \mathrm{M}_{\mathrm{t}-\mathrm{i}}$ where $r=$ interest rate.

If for the moment the interest rate term is ignored, this equation appears quite similar to the transformed Andersen-Jordan equation (1) above. It can be clearly seen from this equation that such specifications of the money demand function relate changes in velocity to current and lagged changes in the money stock (all in logarithms). It further suggests that changes in inter est rates will induce additional changes in velocity.

Most economists would hold that changes in interest rates and money stock are jointly determined, and consequently, forecasts from equation (1), ignoring the induced changes on interest rates from changes in the money stock, will cause forecasting errors. However, if the short-run interest elasticity of the money demand function is very small, then an estimated equation omitting this term would most likely produce a credible forecasting record. In addition, it is likely that the distributed lag on high-employment Govemment expenditures used by Andersen and Jordan is correlated with interest rates in both the sample and post sample periods, and serves as an efective proxy variable for forecasting purposes. ${ }^{32}$

\section{Summary}

Monetarism and the monetarist approach to demand management has raised many isstes in the past several years which have significantly influenced the attitudes of professional economists on the question of

\footnotetext{
3t See Appendix for the derivation.

32 Equations of the form of (3) have been estimated using the data of the current St. Louis forecasting equations, both with and without the high-employment expenditure variables. Space constraints permit only the comment that the interest rate variable, either a short-tem rate such as the Treasury bill rate, or a long-tern rate such as the Corporate Aan rate, show up as highly significant variables, though with very low short run elasticities. Even with the interest rate variable in the specification some of the coefficients in the distributed lag on high-employment expenditures remain significant.
} 
how to pursue stabilization policy. Monetarist models have to date established a forecasting record which is credible when compared to the more entrenched income determination approach.

Recently, considerable work has been done to elaborate an extensive theoretical framework which pur." portedly underlies the policy prescriptions and the "reduced form" monetarist models of aggregate economic activity. The comments above suggest that much of this theoretical framework is shared with economists of nonmonetarist persuasion, but that there are a number of areas in which substantially different views of the world exist. Unfortunately, few attempts have been made by the monetarists and nonmonetarists to identify the common and contrasting elements of their theoretical constructs. Even less work has been done to attempt to disprove the specific hypotheses of market behavior in the areas of conflict, most of which, I believe, involve the dynamics of price adjustments.33 Only as such analysis becomes available will we be able to resolve important policy issues such as the relative strengths of fiscal and monetary actions under various conditions of the economy, and the speed at which policy actions affect aggregate demand, employment, and prices.

33For example, Milton Friedman in, "A Theoretical Framework," argues that a major unresolved issue in his analysis (as well as that of others) is the response of real output and prices individually to policy shocks.

\section{APPENDIX}

The purpose of this appendix is to demonstrate the derivation of equation (3) in the text from a money demand specificution.
Assume that in the long run velocity is a function of interest rates:

(1) $V=F(r) \frac{d F}{d r}>0$
or
(2) $M^{*}=\left[\frac{1}{V}\right] Y=Y g(r) \frac{d g}{d r}<0$

In addition private economic units are assumed to adjust to their long run equilibrium cash balance positions with a lag, which is usually specified as:

(3) $\frac{\mathrm{M}}{\mathrm{M}_{-1}}=\left[\mathrm{M}^{\circ} / \mathrm{M}_{-1}\right]^{\delta}$

When this is expressed in logarithms it becomes:

(4) $\Delta \ln \mathrm{M}=\delta \ln \mathrm{M}^{\circ}-\delta \ln \mathrm{M}_{-1}$

A more general form ${ }^{1}$ of the distributed lag adjustment mechanism can be specified as:

$\ln M=\beta_{0} \ln M^{\circ}+\beta_{1} \ln M_{-1}+\ldots+\beta_{n} \ln M_{-5 t}$

Substituting for $M^{*}$ gives:

(5) $\ln \mathrm{M}=\beta_{\mathrm{o}} \ln [\mathrm{g}(\mathrm{r})]+\beta_{\mathrm{o}} \ln \mathrm{Y}+\sum_{\mathrm{i}=1}^{\mathrm{n}} \beta_{\mathrm{i}} \ln \mathrm{M}_{-\mathrm{i}}$

which can be rewritten as a velocity equation:

(6) $\left.\ln V=(\ln Y-\ln M)=-\beta_{o} \ln \lg (\mathrm{r})\right]+\left(1-\beta_{o}\right) \ln \mathrm{Y}-\sum_{\mathrm{j}=1}^{\mathrm{n}} \beta_{\mathrm{i}} \ln \mathrm{M}_{m i}$

Taking first differences in the logs:

(7) $\Delta \ln V=-\beta_{o} \Delta \ln [g(x)]+\left(1-\beta_{o}\right) \Delta \ln Y-\sum_{i=1}^{n} \beta_{i} \Delta \ln \mathrm{M}_{-i}$ which can be transformed to:

(8) $\Delta \ln V=-\beta_{\mathrm{o}} \Delta \ln [g(\mathrm{r})]+\left(1-\beta_{\mathrm{o}}\right) \Delta \ln \mathrm{V}+\left(\mathrm{I}-\beta_{\mathrm{o}}\right) \Delta \ln \mathrm{M}-\sum_{\mathrm{i}=1}^{\mathrm{n}} \beta_{\mathrm{i}} \Delta \ln \mathrm{M}_{-\mathrm{k}}$ or:

(9) $\Delta \ln V=\frac{1}{\beta_{0}}\left[-\beta_{0} \Delta \ln [g(r)]+\left(1-\beta_{0}\right) \Delta \ln M-\sum_{i=1}^{\beta_{2}} \beta_{i} \Delta \ln M_{-1}\right]$

1Robert M. Solow, "On a Family of Lag Distributions," Econometrica (April 1960), pp. 393-406. 